Journal of Business and Management Studies (JBMS)

ISSN: $2709-0876$

DOI: 10.32996/jbms

Journal Homepage: www.al-kindipublisher.com/index.php/jbms

\title{
Information System Success: Influence to Consumer Behavior in the Use of Mobile Payment in M-Commerce
}

\author{
Dr. Mark Anthony L. Pelegrin \\ Universidad De Manila, Philippines
}

$\square$ Corresponding Author: Dr. Mark Anthony L. Pelegrin, E-mail: markpelegrin@gmail.com

\begin{tabular}{|c|c|}
\hline ARTICLE INFORMATION & ABSTRACT \\
\hline Received: 01 October 2021 & Both businesses and consumers have experienced significant changes as a result of the \\
\hline Accepted: 28 October 2021 & rise of $\mathrm{m}$-commerce. The benefits of using a new system are perceived by users \\
\hline Published: 09 November 2021 & depending on their assessment of the system, information, and service quality. In one \\
\hline DOI: $10.32996 / j b m s .2021 .3 .2 .20$ & $\begin{array}{l}\text { of the cities in the Cavite area, the researcher wants to assess the influence of } \\
\text { information system success in customer behavior in mobile payments in } \mathrm{m} \text {-commerce. }\end{array}$ \\
\hline KEYWORDS & This study consisted of 405 respondents and used purposive and quota sampling with \\
\hline $\begin{array}{l}\text { Information system success, } \\
\text { consumer behavior, mobile } \\
\text { payment, m-commerce }\end{array}$ & $\begin{array}{l}\text { a descriptive quantitative design and a survey questionnaire as the instrument. Analysis } \\
\text { of variance, multivariate analysis of variance, and independent-sample t-test was } \\
\text { considered as statistical techniques that will help determine consumer behavior in the } \\
\text { use of mobile payment in m-commerce. This study's findings have numerous key } \\
\text { implications for the usage of mobile payments in } \mathrm{m} \text {-commerce research. }\end{array}$ \\
\hline
\end{tabular}

\section{Introduction}

The way we pay has recently changed in our society. Today's fast-paced lifestyles necessitate that we continue to find ways to complete more activities with a single click of a button, even if they are as basic as paying utility bills or purchasing groceries and employing cashless methods of transferring payments helps us to do just that. Whether we like it or not, the current economic crisis is forcing people to go digital and many businesses to find new methods of doing business. COVID-19 causes behavioral alterations in humans. The most essential of the multiple mobile commerce applications, such as mobile advertising and mobile gaming, are mobile payment (m-payment) systems, which provide anytime and anywhere payment services via mobile phones. Despite the availability of enabling technology and the potential benefits that $\mathrm{m}$-payment systems offer, their penetration and adoption are still low when compared to other current cashless, non-contact payment choices like credit cards and internet payment systems. The device is used by customers and suppliers to make purchasing and selling decisions as well as execute transactions. Electronic choices and transactions would have an impact on individual users, businesses, marketplaces, and even national economies. The benefits of using a new system are perceived by users depending on their assessment of the system, information, and service quality. Millennials have been at the forefront of the explosive growth of mobile payments. As users use their mobile wallets to purchase products and services, credit cards are set to become obsolete. G-Cash, Smart PayMaya, Paypal, and other payment system operators continue to expand gradually and massively. Despite the fact that $\mathrm{m}$-commerce is a relatively new concept, previous research has produced a wide range of definitions. In this paper, mobile commerce refers to any transaction conducted via a smartphone or any other wireless device that may transfer value in exchange for goods, services, or information. Individuals and organizations are increasingly using mobile commerce to purchase goods and services and pay for them online via mobile payments. Furthermore, they would conduct business online regardless of their profile. As a result, this research contributes to our understanding of how information system success factors influence mobile payment. With the widespread use of mobile payments, it is believed that any uncertainty will have little impact on their behavior.

The research model applied for this study is shown in Figure. 1.

Copyright: (C) 2021 the Author(s). This article is an open access article distributed under the terms and conditions of the Creative Commons Attribution (CC-BY) 4.0 license (https://creativecommons.org/licenses/by/4.0/). Published by Al-Kindi Centre for Research and Development, London, United Kingdom. 


\begin{tabular}{|l|}
\hline \multicolumn{1}{|c|}{ Information System } \\
Success \\
System Quality \\
Information Quality \\
Service Quality
\end{tabular}

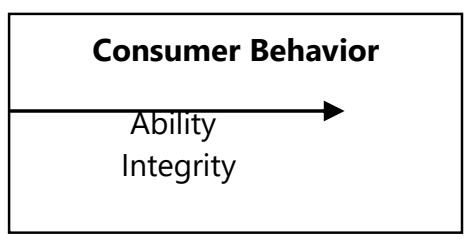

\section{Demographic Profile}

Age,

Gender,

Educational Background

Occupation

Monthly Income/Allowance and

No of Years of Mobile Payment

Experience

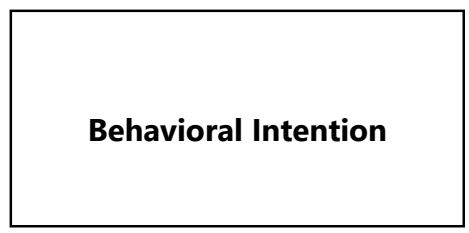

Figure 1. Theoretical and Conceptual Research Model

Because of the growing internet purchasing population of young, urban Filipinos, cashless transactions are on the rise in the Philippines. As a result, the BSP has been working to promote cashless transactions and collaborate with corporate and government institutions to implement cashless solutions. By 2020, the Bangko Sentral ng Pilipinas (BSP) intends to complete its cash-lite initiative, which will see the majority of its financial transactions become digital. According to a Brookings analysis from 2016, the Philippines saw the most significant improvement in digital and financial inclusion, up to eight points from 2015 . The increase in scores was attributed to the increased use of smartphones, mobile money accounts, and the establishment of the Philippine National Strategy for Financial Inclusion (NSFI). Mobile payment is one of these innovations, which is rapidly gaining popularity. Mobile payment is a more mobile form of electronic payment that uses electronic devices connected to a mobile network to execute individual or business transactions.

Delone and McLean's Information System Success (ISS) model evaluates the significant development, delivery, and use of information via technology. From a quality standpoint, the ISS model provides full knowledge of IS success. It asserts that consumers' perceptions of benefits and IS success are favorably influenced by three quality dimensions: perceived system quality, perceived information quality, and perceived service quality. This study's system quality reflects the access speed, ease of use, navigation, and mobile payment system appearance. Owing to mobile terminals' constraints such as small screens and inconvenient input, users may find it challenging to search for information with mobile payment. In this study, perceived information quality reflects the relevance, sufficiency, accuracy, and timeliness of information provided by mobile payment systems. Service quality reflects reliability, responsiveness, assurance, and personalization. Providing quality services will signal service providers' abilities and benevolence. In contrast, if service providers present unreliable services and slow responses to users, they cannot build trust in them.

In this study, consumer behavior is defined as the dynamic interaction of human beings' influence and intellect, behavior, and environmental events by which they share aspects of their lives. Ability refers to the users' perception of the mobile service provider's competency and salient knowledge to deliver the expected service. Integrity refers to users' perceptions that the mobile service provider will be fair, honest, and adhere to reasonable transactions. Behavioral Intention (BI), in terms of $\mathrm{m}$-commerce, can be defined as the likelihood of a user engaging in an online transaction via a mobile device. Further, it may also refer to how an individual will behave in the future and the likelihood of the user engaging in an online transaction via a mobile device.

Because these devices were readily available, developers were able to disrupt the payment industry by creating systems that made such services available to customers. The impact of mobile payments on businesses is enormous. It has fueled rivalry as businesses search out novel ways to leverage technology to outperform competitors, improve service delivery quality, and gain a portion of the mobile payment market. Banks have also joined the race to stay relevant in a fast-moving mobile economy. Knowing customer behavior in the context of $\mathrm{m}$-commerce has become crucial for organizations that want to maximize market penetration and leverage the strength of their social ties. Furthermore, consumers' views and feelings regarding websites and information provided by other consumers have important influences on their purchasing decisions. This study seeks to assess consumers' behavior in the use of mobile payment in $\mathrm{m}$-commerce by paying attention to the information system success, and behavioral intention in one of the cities in Cavite. Specifically, it sought to answer the following questions: 
1. What is the demographic profile of the respondents in terms of Age, Gender, Educational Background, Occupation, Monthly Income/Allowance, and No. of years of Mobile Payment Experience?

2. Is there a significant difference in the assessment between and among the three sample groups of respondents regarding the use of mobile payment in $\mathrm{m}$-commerce in terms of information system success and consumer behavior?

3. Is there a significant difference in the assessment between and among the three sample groups of respondents regarding the use of mobile payment in $\mathrm{m}$-commerce on behavioral intention when grouped according to their profile?

4. What are some recommendations that can be further proposed to mobile payment service providers to establish users' trust in order to encourage and facilitate their adoption and usage of $\mathrm{m}$-payment?

\section{Methods}

A descriptive quantitative design was used in this study. It was conducted in one of the cities in the Cavite area. Non-probability sampling such as purposive and quota sampling was used to obtain reliable information about the study. The respondents of the survey included 405 respondents (students, professionals, and business owners) who had smartphones that allowed them to pay for goods and services using their mobile payments. The instrument used was a survey questionnaire divided into 3 parts: Part 1 profile of the respondents; Part 2 customers' assessment of the use of mobile payment in m-Commerce and Part 3 consumers' assessment of behavioral intention in the use of mobile payment in m-commerce. A statistical technique used was an analysis of variance and multivariate analysis of variance was used to determine the proportion of variability attributed to each of the several components. Furthermore, an independent sample t-test was conducted to compare the two independent groups.

\section{Results and Discussion}

As shown in the findings, these variables play a critical role in favorably impacting consumers' behavior in using mobile payment in $\mathrm{m}$-commerce in one of Cavite's cities. It's also worth noting that the findings of this study back up prior research that used ISS, Consumer Behavior, and Behavioral Intention to examine the use of mobile payment in $\mathrm{m}$-commerce.

Table 1: Demographic profile of respondents $(N=405)$

\begin{tabular}{|c|c|c|c|}
\hline Demographic & Category & Frequency & Percentage \\
\hline \multirow[t]{5}{*}{ Age } & Under 20 & 76 & $19 \%$ \\
\hline & $21-30$ & 123 & $30 \%$ \\
\hline & $31-40$ & 118 & $29 \%$ \\
\hline & $41-50$ & 57 & $14 \%$ \\
\hline & $51-60$ & 31 & $8 \%$ \\
\hline \multirow[t]{2}{*}{ Gender } & Male & 177 & $44 \%$ \\
\hline & Female & 228 & $56 \%$ \\
\hline \multirow[t]{4}{*}{ Educational Background } & TVET School & 5 & $1 \%$ \\
\hline & College Level & 130 & $32 \%$ \\
\hline & College Graduate & 267 & $66 \%$ \\
\hline & Master's Degree & 3 & $1 \%$ \\
\hline \multirow[t]{5}{*}{ Occupation } & Student & 135 & $33 \%$ \\
\hline & Private Employee & 105 & $26 \%$ \\
\hline & Government & & \\
\hline & Employee & 30 & $7 \%$ \\
\hline & Self-employed & 135 & $33 \%$ \\
\hline \multirow[t]{7}{*}{ Monthly Income/Allowance } & Less than & & \\
\hline & P 5,000 & 135 & $33 \%$ \\
\hline & $\begin{array}{l}\text { P 5,001 - } \\
\text { P 15,000 }\end{array}$ & - & - \\
\hline & P $15,001-$ & & \\
\hline & P 25,000 & 60 & $15 \%$ \\
\hline & $\begin{array}{l}\text { P } 25,001- \\
\text { P } 35,000\end{array}$ & 120 & $30 \%$ \\
\hline & Over P 35,000 & 90 & $22 \%$ \\
\hline \multirow[t]{4}{*}{ No of years of mobile payment experience } & $6-12$ months & 51 & $13 \%$ \\
\hline & $1-2$ years & 84 & $21 \%$ \\
\hline & $2-3$ years & 113 & $28 \%$ \\
\hline & Over 3 years & 157 & $39 \%$ \\
\hline
\end{tabular}


As shown in Table 1, most of the respondents were in the age group of 21 - 30 years, primarily female, college graduates, having an occupation as students and self-employed, with monthly income/allowance of less than P 5,000 and P 25,001 - P 35,000, respectively, and had a mobile payment experience of over 3 years.

Table 2: MANOVA results among the three sample groups of respondents in the use of mobile payment in $m$-commerce in terms of Information System Success and Consumer Behavior

\begin{tabular}{|c|c|c|c|c|c|c|}
\hline Source & $\begin{array}{l}\text { Dependent } \\
\text { Variable }\end{array}$ & $\begin{array}{l}\text { Mean } \\
\text { Square }\end{array}$ & $\mathrm{F}$ & Sig & Interpretation & Decision \\
\hline \multirow{2}{*}{ Group } & System Quality & .014 & .148 & .863 & \multirow{3}{*}{ Not Significant } & \multirow{3}{*}{ Accept the Null Hypothesis } \\
\hline & Ability & .026 & .266 & .767 & & \\
\hline \multicolumn{4}{|c|}{ Wilks' Lambda } & .870 & & \\
\hline \multirow[t]{2}{*}{ Group } & $\begin{array}{l}\text { Information } \\
\text { Quality }\end{array}$ & .026 & .322 & .725 & \multirow{3}{*}{ Not Significant } & \multirow{3}{*}{ Accept the Null Hypothesis } \\
\hline & Ability & .026 & .266 & .767 & & \\
\hline \multicolumn{2}{|c|}{ Wilks' Lambda } & & & .932 & & \\
\hline \multirow{2}{*}{ Group } & Service Quality & .042 & .501 & .606 & \multirow{3}{*}{ Not Significant } & \multirow{3}{*}{ Accept the Null Hypothesis } \\
\hline & Ability & .026 & .266 & .767 & & \\
\hline \multicolumn{4}{|c|}{ Wilks' Lambda } & .897 & & \\
\hline \multirow{2}{*}{ Group } & System Quality & .014 & .148 & .863 & \multirow{3}{*}{ Not Significant } & \multirow{3}{*}{ Accept the Null Hypothesis } \\
\hline & Integrity & .007 & .083 & .920 & & \\
\hline \multicolumn{4}{|c|}{ Wilks' Lambda } & .967 & & \\
\hline \multirow[t]{2}{*}{ Group } & $\begin{array}{l}\text { Information } \\
\text { Quality }\end{array}$ & .026 & .322 & .725 & \multirow[t]{3}{*}{ Not Significant } & \multirow{3}{*}{ Accept the Null Hypothesis } \\
\hline & Integrity & .007 & .083 & .920 & & \\
\hline \multicolumn{2}{|c|}{ Wilks' Lambda } & & & .899 & & \\
\hline \multirow{2}{*}{ Group } & Service Quality & .042 & .501 & .606 & \multirow{3}{*}{ Not Significant } & \multirow{3}{*}{ Accept the Null Hypothesis } \\
\hline & Integrity & .007 & .083 & .920 & & \\
\hline \multicolumn{2}{|c|}{ Wilks' Lambda } & & & .846 & & \\
\hline
\end{tabular}

A one-way MANOVA was calculated by examining the Information System Success variables and Consumer Behavior and it had no effect among the three sample groups of respondents, as illustrated in Table 2. No significant difference was found (Lambda $(4,802)=.870, .932, .897, .967, .899$ and $.846, p>.05)$. The respondents' group significantly influenced neither System Quality, Information Quality, and Service Quality in terms of Ability and Integrity.

Table 3: ANOVA results between the three sample groups in the use of mobile payment in m-commerce on Behavioral Intention when grouped according to Profile

\begin{tabular}{|c|c|c|c|c|c|c|c|}
\hline Dimensions & $d f$ & $\begin{array}{l}\text { Mean } \\
\text { Square }\end{array}$ & $F$ & Sig & Interpretation & Decision & \\
\hline Age & $\begin{array}{r}4 \\
400 \\
404 \\
\end{array}$ & $\begin{array}{l}.116 \\
.098\end{array}$ & 1.193 & .313 & Not Significant & $\begin{array}{l}\text { Accept the } \\
\text { Hypothesis }\end{array}$ & Null \\
\hline $\begin{array}{l}\text { Educational } \\
\text { Background }\end{array}$ & $\begin{array}{r}3 \\
401 \\
404 \\
\end{array}$ & $\begin{array}{l}.018 \\
.098\end{array}$ & .181 & .910 & Not Significant & $\begin{array}{l}\text { Accept the } \\
\text { Hypothesis }\end{array}$ & Null \\
\hline Occupation & $\begin{array}{r}3 \\
401 \\
404 \\
\end{array}$ & $\begin{array}{l}.027 \\
.098\end{array}$ & .271 & .846 & Not Significant & $\begin{array}{l}\text { Accept the } \\
\text { Hypothesis }\end{array}$ & Null \\
\hline $\begin{array}{l}\text { Monthly Income / } \\
\text { Allowance }\end{array}$ & $\begin{array}{r}3 \\
401 \\
404 \\
\end{array}$ & $\begin{array}{l}.031 \\
.098\end{array}$ & .312 & .816 & Not Significant & $\begin{array}{l}\text { Accept the } \\
\text { Hypothesis }\end{array}$ & Null \\
\hline $\begin{array}{l}\text { No. of Years of Mobile } \\
\text { Payment Experience }\end{array}$ & $\begin{array}{r}3 \\
401\end{array}$ & $\begin{array}{l}.059 \\
.098\end{array}$ & .600 & .616 & Not Significant & $\begin{array}{l}\text { Accept the } \\
\text { Hypothesis }\end{array}$ & Null \\
\hline
\end{tabular}


As seen in Table 3, the findings back with earlier research, as millennials are driving many of these exciting advances. Park J. claims that younger consumers appear to be more tolerant and open to new technology than older consumers, according to et al. (2018). Education has always been seen as a critical aspect in the adoption of new technology. It is expected that understanding the mechanisms of modern technology will necessitate a certain level of knowledge. Education hasn't always been a reliable predictor of technology's use as a retail medium. With the currently available mobile payment methods, users with employment as a source of income feel more comfortable and trusting. This means that employed people are more likely to accept available mobile payment systems. Given the nature of internet purchases, it's safe to presume that online customers have a solid salary. Most Filipino internet buyers, according to Rappler (2016), have a middle-class salary. According to Janio Asia (2019), active Internet users account for $71 \%$ (76 million) of the country's total population of 107.3 million people. Seventy percent of those surveyed had purchased a product or service online in the previous month. These are Gen Z and millennials who are tech-savvy and heavy users of social media.

Table 3.1: $t$-test results among the three sample groups of male and female respondents in the use of mobile payment in $m$ commerce on Behavioral Intention

\begin{tabular}{|c|c|c|c|c|c|c|c|c|c|}
\hline & \multirow{3}{*}{$\mathrm{N}$} & \multirow{3}{*}{ Mean } & \multirow{3}{*}{ Std. Deviation } & \multirow{3}{*}{$\mathrm{t}$} & \multirow{3}{*}{$d f$} & Leven & Test fo & \multirow{3}{*}{$\begin{array}{l}\text { Interpretation } \\
\text { Decision }\end{array}$} & \multirow[t]{3}{*}{1} \\
\hline & & & & & & \multicolumn{2}{|c|}{ Equality of Variances } & & \\
\hline & & & & & & $\frac{r}{200}$ & $\frac{\mathrm{sig}}{648}$ & & \\
\hline Female & 228 & 3.55 & .306 & & & & & $\begin{array}{l}\text { Accept the Null } \\
\text { Hypothesis }\end{array}$ & \\
\hline
\end{tabular}

Gender has traditionally played a role in how a family makes purchasing decisions. Consumers utilize mobile payments because they are practical and convenient, especially with the introduction of internet purchasing. The urge to maximize advantages while minimizing risk drives the motivation to shop. Furthermore, mobile payment is a one-on-one process in which customers have little to no engagement with salespeople. According to the Digital Report (2019), more women (12\%) shop online than males (8\%) in the Philippines, despite the fact that women hold fewer credit cards. Based on the values presented in the above tables, the outline of the findings revealed the following:

Despite their strong agreement, merchants are faceless when it comes to mobile payments, therefore the quality of their systems becomes the online focal point by which impressions are formed. Users may believe that service providers lack the expertise and integrity to provide excellent services if mobile payment systems are difficult to use and have a poor interface design. It clearly demonstrates that respondents could pay bills and obtain payment information via mobile payment at any time and from any location. They do, however, expect to get complete, accurate, and timely transaction information, such as transaction records and paperwork. Users are still concerned about whether the payment was finished, whether the settlement occurred, and whether the short return message will arrive promptly after the payment was done.

It is apparent that respondents strongly agree that mobile payment provides high-quality services. However, it was revealed that the focus is on mobile network dependability, which is a typical issue among customers who are concerned that the network connection would go down during a financial transaction. Users may distrust service providers' capacity to provide quality services if they face inaccessible service connections and service interruptions while interacting with mobile payment systems. Despite physical limitations such as limited display screens or data entry, respondents find a mobile payment to be extremely convenient. Even in developing nations with significant mobile phone penetration, m-commerce applications are still a novelty for customers, and adoption may be gradual, especially among inexperienced users. Respondents clearly believe that their mobile payment service providers have the requisite knowledge and experience to complete their jobs and that their general ability to meet most client requests is unquestionable. Respondents who give an online firm a high rating for power are more inclined to think of it as having high integrity.

Furthermore, it may be assumed that their mobile payment service providers are more likely to be trusted by consumers in a certain sector (such as banking) than those with less apparent knowledge. Users' opinions of service providers' traits, such as providers' ability and honesty, are referred to as trusting beliefs in mobile payment services by Yu et al. (2018). Users will be delighted with mobile payment and positively rate such a service if they view the mobile payment service provider to be reputable and generally trustworthy. Users that do not trust mobile payment may be displeased with the service and give it a low rating. 
Consumers having a higher intention to accept new technology are more likely to become adopters and advocate the technology to others, according to Sunny et al. (2018). Businesses can utilize social networks as a platform to share their ideas and perspectives on the mobile payment system, commodities, and technologies, which creates many challenges and opportunities.

\section{Conclusions and Implications}

The main objectives of this research were to (1) assess the consumers' behavior in the use of mobile payment in $\mathrm{m}$-commerce in one of the cities in the Cavite area, and (2) identify any differences between and among the factors. To achieve these objectives, a research model comprising three sample groups (students, professionals, and business owners) and six variables, System Quality (SYSQ), Information Quality (INFQ), Service Quality (SERQ), Ability (ABI), Integrity (INT), and Behavioral Intention (BEHI).

The research found that Cavite respondents generally accepted mobile payments, but mobile payment is not yet widely used in daily life. Most respondents strongly agree on most aspects of the variables in the use of mobile payment despite uncertainties and it indicates mobile payment provides good performance on consumers' behavior and is similar to the actual situation.

Based on the conclusions and significant findings, doing online transactions is convenient, where Filipinos have limited time to physically perform their necessary tasks such as paying their utilities or sending money to their relatives. The following are with this offered:

As shown in the increase of confidence and trust among Cavite users in digital transactions, they should continue and support mobile payment adoption in m-commerce. Moreover, it showed them the benefits and advantages of this trading system since they conduct transactions anytime and anywhere. Further, with the continuance of mobile payment in $\mathrm{m}$-commerce, it perfectly fits the respondents' nature of modern lifestyle, providing a means for shopping and service to deliver virtually any life situation.

The study results can help manage mobile companies and m-commerce providers to build a stable base of loyal customers. As mobile services are still relatively new, educational and marketing strategies that illustrate this trading system's advantages are essential. The value of using $\mathrm{m}$-commerce systems for enhancing market activities and operational efficiency is especially noteworthy. Moreover, mobile service providers need to attach considerable importance to delivering quality information to users. It would be also well-advised to provide personalized information about their account balance and payment records. Information quality improvement will require mobile service providers' continuous effort and resource investment. It is also recommended that $\mathrm{m}$-payment systems should be well designed so that the payment procedure is straightforward and easy to execute. Thus $\mathrm{m}$ payment service providers need to simplify the operation process and improve users' perceived convenience. The number of steps involved in the process should be minimized to reduce complexity, and adequate feedback to the user regarding the status of the transaction is also helpful to avoid any confusion. M-commerce has created a new definition in modern-day marketing. It helps businesses provide a better and consistent experience in fulfilling customers' and businesses' needs that embrace the digital transformation stands a chance of engaging and serving their customers quickly. Nowadays, customers want to get things done quicker than usual, and they buy from a company that can fulfill speedy processes. Through digital transformation, companies can convert tangible goods into digital goods to meet their customers' needs. The data collection and analysis process has opened up new opportunities for digital businesses. It helps to further enhance business strategies by studying the online habits of consumers. Improving customer experiences and engagement leads to customer loyalty. In turn, the customers stick with your company with more deals.

Moreover, digital transformation opens the door for new sales channels and markets. By transforming the company into a digital business, they are keeping pace with the competition. Furthermore, this will have favorable change on everything that revolves around the industry. Although this study has been conducted with methodological rigor, the findings should be interpreted with caution. First, the research conducted was only in one of the cities in the Cavite area, which in terms of characteristics, is different from other cities. Therefore, future studies could replicate the same research in different contexts or conduct a comparative study. Second, besides the factors identified in this study, there may exist other factors affecting consumer behavior, such as individual user characteristics. Future research could explore further extensions of the research model used in this study with such constructs. Third, future researchers could increase the number of respondents and recognize other variables that could contribute to Filipinos' perception of mobile commerce; this research study can be further enhanced and validated through a more extended period of collecting data. Finally, for better results, more advanced statistical techniques can be applied.

\section{References}

[1] Abner, I. P., Samuel, U. E., Jack, A. E., \& Kanu, C. (2019). Current and Potential Users Adoption of Mobile Payment Technology in Nigeria System, 6, 21. International Journal of Recent Technology and Engineering (IJRTE) ISSN: 2277-3878, Volume-8 Issue-4. 
[2] Ali S., \& Al-Ajam K. (2015), Challenges of adoption of internet banking service in Yemen, International Journal of Bank Marketing, Vol. 33. 178 - 194: http://dx.doi.org/10.1108/JJBM-01-2013-0001

[3] Alqatan, S., Mohamad-Noor, N.M., Man, M. and Mohemad, R. (2019) An empirical study on factors affecting the acceptance of M-commerce application among small and medium-sized tourism enterprises by integrating TTF with TAM, Int. J. Business Information Systems, Vol. 31, No. 1.106-135.

[4] Al-Sondos, I., \& Salameh, A. (2020). The effect of system quality and service quality toward using m-commerce service, based on the consumer perspective. Management Science Letters, 10(11), 2589-2596.

[5] Barry, M., \& Jan, M. T. (2018). Factors influencing the use of M-commerce: An extended technology acceptance model perspective. International Journal of Economics, Management, and Accounting, 26(1), 157-183.

[6] Cao, X., Yu, L., Liu, Z., Gong, M. and Adeel, L. (2018), Understanding mobile payment users' continuance intention: a trust transfer perspective, Internet Research, Vol. 28 No. 2. 456-476. https://doi.org/10.1108/IntR-11-2016-0359

[7] Chaiyasoonthorn, W. (2019). Decision Making in Selecting Mobile Payment Systems. 126-139. https://doi.org/10.3991/ijim.v13i09.10834

[8] Chatterjee, S., Kar, A. K., \& Gupta, M. P. (2018). The success of IoT in Smart Cities of India: An empirical analysis. Government Information Quarterly, 35(3), 349-361. doi:10.1016/j.giq.2018.05.002

[9] Chen, Q., Zhang, M., \& Zhao, X. Analysing customer behavior in mobile app usage. Industrial Management \& Data Systems, vol. 117, no. 2. 425 438, 2017. https://doi.org/10.1108/IMDS-04-2016-0141.

[10] Chhonker, M.S., Verma, D. and Kar, A.K. (2017), Review of technology adoption frameworks in mobile commerce, Procedia Computer Science, Vol. 122, 888-895.

[11] Ching, M. R. D. (2017). Challenges and Opportunities of Electronic Payment Systems in the Philippines. In DLSU Research Congress.

[12] Chuang, L.M., Liu, C.C., \& Kao, H.K. (2016). The Adoption of Fintech Service: TAM perspective. International Journal of Management and Administrative Sciences (IJMAS), 3(07), 1-15.

[13] Dahlberg, T., Guo, J., \&Ondrus, J. (2015). A critical review of mobile-payment research. Electronic Commerce Research and Applications, 14(5), 265-284. doi:10.1016/j.elerap.2015.07.006

[14] DeLone, W. H., \& McLean, E. R. (2016). Information Systems Success Measurement. Foundations and Trends ${ }^{\circledR}$ in Information Systems, 2(1), 1116. doi:10.1561/2900000005

[15] De Kerviler, G., Demoulin, N. T. M., \& Zidda, P. (2016). Adoption of in-store mobile payment: Are perceived risk and convenience the only drivers? Journal of Retailing and Consumer Services, 31, 1-39.

[16] De Kerviler, G., \&Demoulin, N. T. (2017). Making in-store payment enjoyable by adopting mobile payment.Annales des Mines-Réalités industrielles, 4, 64-68.

[17] Faqib, K.M., and Jaradat, (2015) M.I.R.M. Assessing the Moderating Effect of Gender Difference and Individualism-Collectivism at IndividualLevel on the Adoption of M-commerce Technology: TAM3 Perspective. Journal of Retailing and Consumer Services 22 (2015) 37-52.

[18] Fong, K.K. and Wong, S.K.S. (2015) Factors Influencing the Behavior Intention of Mobile Commerce Service Users: An Exploratory Study in Hong TURKU UNIVERSITY OF APPLIED SCIENCES| Chu Phuong Anh 59 Kong, International Journal of Business and Management, vol. 10, no. 7, 39-47.

[19] Gao, L., \& Waechter, K. A. (2015). Examining the role of initial trust in user adoption of mobile payment services: an empirical investigation. Information Systems Frontiers, 19(3), 525-548. doi:10.1007/s10796-015-9611-0

[20] Gumba, B. (2019). Socioeconomic Factors Influencing Participation in Mobile Money by Poor Fishing Families of a Municipality in the Philippines. Southeast Asian Journal of Science and Technology, 4(1), 101-107.

[21] Groß, M., 2015.Mobile shopping: a classification framework and literature review. Int. J. Retail Distrib. Manag.43(3),221-241.

[22] Hasan, R., Liu, Y., Kitchen, P. J., \& Rahman, M. (2019). Exploring consumer mobile payment adoption in the bottom-of-the-pyramid context: A qualitative study. Strategic Change, 28(5), 345-353.

[23] Hedman, J. and S. Henningsson, (2015). The new normal: Market cooperation in the mobile payments ecosystem. Electronic Commerce Research and Applications, 2015. 14(5): 305-318.

[24] Hussain, M., Mollik, A. T., Johns, R., \& Rahman, M. S. (2018). M-payment adoption for the bottom of pyramid segment: an empirical investigation. International Journal of Bank Marketing. doi:10.1108/ijbm-01-2018-0013

[25] Jamaliah, W., Jusoh, W., \& Adewale, A. A. (2016). An Examination Factors Influencing The Intention to Adopt Internet Banking Among SMEs in Yemen: Using An Extension of The Technology Acceptance Model (TAM). Journal of Internet Banking and Commerce21(November).

[26] Jiwasiddi, A., Adhikara, C., Adam, M., \&Triana, I. (2019). Attitude toward using Fintech among Millennials. (26-28 January 2019$), 10$. https://doi.org/10.4108/eai.26-1-2019.2283199

[27] John S and Amos G (2019). FinTech in the Philippines: Assessing the State of Play. @2019 Milken Institute.

[28] Jungkun P, Amendah, Y and Lee H. H. (2018). M-payment service: Interplay of perceived risk, benefit, and trust in service adoption https://doi.org/10.1002/hfm.20750

[29] Kalinic, Z., Marinkovic, V., Molinillo, S., \& Liébana-Cabanillas, F. (2019). A multi-analytical approach to peer-to-peer mobile payment acceptance prediction. Journal of Retailing and Consumer Services, 49, 143-153. doi:10.1016/j.jretconser.2019.03.016

[30] Kang, J.-Y.M., Mun, J.M., Johnson, K.K.P.,2015. In-store mobile usage: downloading and usage intention toward mobile location-based retail apps. Comput. Hum. Behav.46, 210-217.

[31] Ketelaar, P. E., Willemsen, L. M., Sleven, L., \& Kerkhof, P. (2015). The good, the bad, and the expert: How consumer expertise affects review valence effects on purchase intentions in online product reviews. Journal of Computer-Mediated Communication, vol. 20, no. 6, 649-666, 2015. https://doi.org/10.1111/jcc4.12139.

[32] Koenig-Lewis, N., Marquet, M., Palmer, A., \& Zhao, A. L. (2015). Enjoyment and social influence: predicting mobile payment adoption. The Service Industries Journal, 35(10), 537-554.

[33] Koul, S., \&Eydgahi, A. (2017). A systematic review of technology adoption frameworks and their applications. Journal of Technology Management \& Innovation, 12(4), 106-113. doi:10.4067/s0718-27242017000400011 
[34] Kumar, K. S., Sivashanmugam, C., \& Venkataraman, A. (2017). Intention to use mobile wallet: extension of TAM model, International Journal of Current Engineering and Scientific Research, 4 (12), 5-11.

[35] Lau, M. M., Lam, A. Y. C., Cheung, R., \& Leung, T. F. (2019). Understanding determinants of customer behavioral intention in using mobile payment at convenience stores. Proceedings of the 10th International Conference on E-Education, E-Business, E-Management, and E-Learning - IC4E '19. doi:10.1145/3306500.3306549

[36] Lee, J., Lee, J.N., \& Tan, B.C. (2015). Antecedents of cognitive trust and affective distrust and their mediating roles in building customer loyalty. Information Systems Frontiers, 17(1), 159-175.

[37] Liébana-Cabanillas, F., Marinkovic, V., Ramos de Luna, I., \&Kalinic, Z. (2018). Predicting the determinants of mobile payment acceptance: A hybrid SEM-neural network approach. Technological Forecasting and Social Change, 129, 117-130. doi:10.1016/j.techfore.2017.12.015

[38] Lin, K. Y., Wang, Y., T., \& Huang, T. K. (2018, January). What drives continued intention for mobile payment?-an expectation cost-benefit theory with habit. In Proceedings of the 51st Hawaii International Conference on System Sciences.

[39] Lin, Wu, Lim, Han, \& Chen. (2019). Understanding the Sustainable Usage Intention of Mobile Payment Technology in Korea: cross-countries Comparison of Chinese and Korean Users. Sustainability, 11(19), 5532. doi:10.3390/su11195532

[40] Lingling Yu, Xiongfei Cao, Zhiying Liu, Mingchuan Gong, Luqman Adeel, Understanding mobile payment users' continuance intention: a trust transfer perspective, Internet Research, https://doi.org/10.1108/IntR-11-2016-0359

[41] Liu, J., R.J. Kauffman, and D. Ma (2015). Competition, cooperation, and regulation: Understanding the evolution of the mobile payments technology ecosystem. Electronic Commerce Research and Applications, 2015. 14(5): p. 372-391.

[42] M. Obaid, Z. Bayram, and M. Saleh, Instant Secure Mobile Payment Scheme, in IEEE Access, vol. 7,. 55669-55678, 2019, DOI: 10.1109/ACCESS.2019.2913430.

[43] Malter, A. J., \& Rindfleisch, A. (2019). Transitioning to a digital world. In A. Rindfleisch\& A. J. Malter (Eds.), Marketing in a Digital World (forthcoming). Bingley: Emerald Books.

[44] McLeod, S. A. (2019, May 20). What a p-value tells you about statistical significance. Simply Psychology. https://www.simplypsychology.org/p-value.html

[45] Nazir. A, P. W. Handayani, and F. Azzahro, Factors Influencing Continuance Usage of Mobile Wallets in Indonesia, 2018 International Conference on Information Management and Technology (ICIMTech), Jakarta, 2018, 92-97, DOI: 10.1109/ICIMTech.2018.8528157.

[46] Nazri. H. Social commerce constructs and consumer's intention to buy, International Journal of Information Management 35 (2015) 183-191

[47] Obaid, M., Bayram, Z., \& Saleh, M. (2019). Instant Secure Mobile Payment Scheme. IEEE Access, 1-1. doi:10.1109/access.2019.2913430

[48] Park, J., Amendah, E., Lee, Y., \& Hyun, H. (2018). M-payment service: Interplay of perceived risk, benefit, and trust in service adoption. Human Factors and Ergonomics in Manufacturing \& Service Industries. doi:10.1002/hfm.20750

[49] Rajan A, Rohit S, Samuele S., Srikanth A, and Well, S. e-Conomy SEA 2018 (Google and Temasek, November 2018).

[50] Rindfleisch, A. (2019). Transaction cost theory: past, present, and future. AMS Review. doi:10.1007/s13162-019-00151-x

[51] Saprikis, V., Markos, A., Zarmpou, T., \&Vlachopoulou, M. (2018). Mobile Shopping Consumers' Behavior: An Exploratory Study and Review. Journal of Theoretical and Applied Electronic Commerce Research, 13(1), 71-90. doi:10.4067/s0718-18762018000100105

[52] Sharma, S. K., \& Sharma, M. (2019). Examining the role of trust and quality dimensions in the actual usage of mobile banking services: An empirical investigation. International Journal of Information Management, 44, 65-75. doi:10.1016/j.ijinfomgt.2018.09.013

[53] Shrier, D., G. Canale, and A. Pentland (2016). Mobile money \& payments: Technology trends. 2016, MIT Connection Science's series on financial technology.

[54] Singh, N., Sinha, N., \& Liébana-Cabanillas, F. J. (2020). Determining factors in the adoption and recommendation of mobile wallet services in India: Analysis of the effect of innovativeness, stress to use, and social influence. International Journal of Information Management, 50, 191205.

[55] Singh, S., Zolkepli, I. A., \& Cheah, W. K. (2018). New Wave in Mobile Commerce Adoption via Mobile Applications in Malaysian Market: Investigating the Relationship Between Consumer Acceptance, Trust, and Self Efficacy. International Journal of Interactive Mobile Technologies (ilM), 12(7), 112. doi:10.3991/ijim.v12i7.8964

[56] Slade, E., Williams, M., Dwivedi, Y. and Piercy, N. (2015), Exploring consumer adoption of proximity mobile payments, Journal of Strategic Marketing, Vol. 23 No. 3. 209-223.

[57] Sun, S., Law, R., \&Schuckert, M. (2020). Mediating effects of attitude, subjective norms, and perceived behavioral control for mobile payment-based hotel reservations. International Journal of Hospitality Management, 84, 102331. doi:10.1016/j.ijhm.2019.102331

[58] Sunny, P., \& George, A. (2018). Determinants of Behavioral Intention To Use Mobile Wallets-a Conceptual Model. Journal of Management (JOM), 5(5).

[59] Suyanto, T. A. K. (2019). Factors Affecting the Confidence Level of FinTech Use in MSMEs Using the Technology Acceptance Model (TAM). Akmenika, 16(1).

[60] Teo, A. C., Tan, G. W. H., Ooi, K. B., Hew, T. S., \& Yew, K. T. (2015). The effects of convenience and speed in m-payment. Industrial Management \& Data Systems, 115(2), 311-331. doi:10.1108/IMDS-08-2014-0231

[61] Widyanto, H. A., Kusumawardani, K. A., \&Septyawanda, A. (2020). ENCOURAGING BEHAVIORAL INTENTION TO USE MOBILE PAYMENT: AN EXTENSION OF UTAUT2. Jurnal Muara Ilmu Ekonomi dan Bisnis, 4(1), 87-97.

[62] Williamson, O. E. (2016). The transaction cost economics project: origins, evolution, utilization. The Elgar Companion to Ronald H. Coase, 3442. doi:10.4337/9781782547990.00011

[63] Yadav, R., Sharma, S. K., \& Tarhini, A. (2016). A multi-analytical approach to understanding and predicting mobile commerce adoption. Journal of Enterprise Information Management, vol. 29, no. 2. 222-237, 2016. https://doi.org/10.1108/JEIM-04-2015-0034.

[64] Yuan, S., Liu, L., Su, B., \& Zhang, H. (2020). Determining the antecedents of mobile payment loyalty: Cognitive and affective perspectives. Electronic Commerce Research and Applications, 100971.doi:10.1016/ j.elerap.2020.100971

[65] Zhang, Y., Sun, J., Yang, Z., \& Wang, Y. (2018). What makes people actually embrace or shun mobile payment: A cross-culture study. Mobile information systems, 2018.

[66] Zhou, T. (2013). An empirical examination of continuance intention of mobile payment services. Decision support systems, 54(2), 1085-1091. 


\section{Websites}

[1] https://www.adb.org/news/cloud-based-banking-pilot-project-improve-financial-inclusion-philippines. July $26,2017$.

[2] https://www.americanexpress.com/us/foreign-exchange/articles/china-mobile-payment-markets/

[3] https://www.bigcommerce.com/blog/mobile-commerce/\#are-there-different-types-of-mobile-commerce

[4] http://www.bsp.gov.ph/publications/media.asp?id=3948

[5] http://www.bsp.gov.ph/downloads/Publications/2018/FIP_1Sem2018.pdf

[6] https://www.bworldonline.com/filipinos-still-prefer-in-store-shopping-over-online-sites/

[7] https://www.bworldonline.com/digitizing-social-payments-to-yield-govt-savings/ December 10, 2019

[8] https://callygood.medium.com/7-business-benefits-of-digital-transformation-6e78c3affd64

[9] https://www.capgemini.com.resource-file-access/resource/pdf/payments_trends_2016.pdf.

[10] https://www.coursehero.com/file/p491abh/j-Service-provider-refers-to-a-provider-of-i-On-line-services-or-network-access/

[11] https://www.coursehero.com/file/p7pfj4v/g-Electronic-Key-refers-to-a-secret-code-which-secures-and-defends-sensitive/

[12] http://www.emarketer.com/Article/Smartphones-Still-Browsing-More-than- Buying/1013065), October 6 (accessed20.10.15).

[13] http://www.firstannapolis.com/news/apple-pay-awareness-adoption-plateau-according-to-first-Annapolis-survey-2016

[14] http://www.gfk.com/news-and-events/press-room/press-releases/pages/shoppers-bringing-online-competition-inside-bricks-and-mortar-stores.aspx). GfK, 2015

[15] https://www.globenewswire.com/news-release/2019/05/15/1824589/0/en/Global-Mobile-Commerce-M-Commerce-Market-2019-is-set-to-be-a-Billion-DollarIndustry-by-2026-According-to-Market-Forecasts-MRS-Research-Group.html

[16] https://www.gsma.com/mobileeconomy/asiapacific/

[17] https://www.igi-global.com/dictionary/extension-technology-acceptance-model-hospital/22282

[18] https://www.itproportal.com/features/digital-payments-in-2018-how-millennials-are-driving-next-gen-commerce/

[19] https://www.lawphil.net/statutes/repacts/ra2000/ra_8792_2000.html

[20] https://www.lawphil.net/statutes/repacts/ra2012/ra_10173_2012.html

[21] https://www.luxurysociety.com/articles/2015/06/is-thailands-luxury-market-making-a-comeback

[22] http://www.philippineasiannewstoday.com/frontpageslider/filipinos-embrace-mobile-banking/

[23] https://www.philstar.com/business/2019/11/18/1969603/bsp-gives-nod-8-more-payment-system-operators

[24] https://www.philstar.com/business/2019/11/18/1969603/business

[25] https://www.philstar.com/business/banking/2019/11/05/1965957/bsp-issues-provisional-licenses-10-payments-operators

[26] https://www.privacy.gov.ph/data-privacy-act/

[27] https://www.privacyph.net/2019/03/28/the-data-privacy-act-bar-exam-guide/

[28] https://www.rappler.com/brandrap/finance-and-industries/134852-ecommerce-industry-philippines

[29] https://www.slideshare.net/DataReportal/digital-2019-philippines-january-2019-v01

[30] https://www.statista.com/statistics/1105585/philippines-usage-e-payment-method-by-gender/

[31] https://www.wipo.int/edocs/lexdocs/laws/en/ph/ph028en.pdf

\section{Internet}

[1] https://blog.euromonitor.com/thailand-and-philippines-new-hotspots-for-m-commerce/

[2] https://boi.gov.ph/r-a-8792-electronic-commerce-act-of-2000/

[3] https://businessinquirer.net/26448.Business Inquirer. 2019. At $10 \mathrm{hrs} ., 2$ mins a day, Filipinos spend the most time online.

[4] https://business.inquirer.net/240416. Business Inquirer. November 09, 2017. more-filipinos-embrace-mobile-banking-for-convenience-with-bill-paymentsmoney-transfer-survey\#ixzz6Mhc5AiKp

[5] https://digitalfilipino.com/the-philippines-e-commerce-law-republic-act-no-8792/

[6] http://docplayer.net/3623911-Simplicity-is-the-ultimate-sophistication.html?cv=1

[7] http://edutechwiki.unige.ch/en/Technology_acceptance_model

[8] http://everything.explained.today/F-test/

[9] https://goo.gl/s9hswP. Philippine Payments Management, Inc., January 2019. The list was last accessed by the authors on January 23, 2019.

[10] https://www.imoney.ph/articles/ph-digital-economy-forecasted-to-reach-25-billion-in-2025/

[11] https://janio.asia/articles/who-are-philippines-online-shoppers/2019/06/26

[12] https://milkeninstitute.org/sites/default/files/reports-pdf/FinTech-in-the-Philippines-Update\%20\%281\%29.pdf

[13] https://www.paymaya.com/stories/how-cashless-payment-solutions-benefit-merchants-and-consumers-alike

[14] https://privacy.com.ph/learn-data-privacy-compliance/data-privacy-faqs/

[15] https://privacy.com.ph/learn-data-privacy-compliance/what-is-processing-of-personal-information/

[16] https://privacy.com.ph/learn-data-privacy-compliance/data-privacy-faqs/

[17] https://privacy.com.ph/learn-data-privacy-compliance/what-is-the-scope-of-the-data-privacy-act/

[18] https://scholarworks.waldenu.edu/cgi/viewcontent.cgi?article=12126\&amp;context=dissertations

[19] https://searchcio.techtarget.com/definition/strategic-plannin

[20] https://smart.com.ph/About/profile/innovations-and-awards/smart-mone

[21] https://www.theseus.fi/bitstream/handle/10024/356143/Njoh_Maxime.pdf?isAllowed=y\&sequence $=2$

[22] https://wearesocial.com/blog/2018/01/global-digital-report-2018

[23] https://wnot.com.ph/2015/02/24/technology/lazada-com-ph-unveils-the-filipino-purchase-behaviour-through-mobile-commerce/

[24] https://www.rappler.com/brandrap/finance-and-industries/134852-ecommerce-industry-philippines 